10.2478/cer-2013-0031

EDWARD MOLENDOWSKI*, MAŁGORZATA ŻMUDA**

\title{
Changes In Competitiveness Among The Visegrad Countries After Accession To The European Union: A Comparative Analysis Based On A Generalized Double Diamond Model
}

\begin{abstract}
National competitiveness is a buzzword that awakens much interest and controversy. In its broadest perspective, it is seen as a modern way of describing the development efforts of nations in the times of globalization (Reinert 2001, p. 23-42). This means that forces driving the changes in the global economy: liberalization of international trade, booming investment by multinational enterprises and development of regional integration groupings, need to be included into the competitiveness model. Well-known and commonly used approach to national competitiveness: Porter's diamond of competitive advantage does not however capture this international context. By concentrating solely on the elements of the domestic environment, the model does not show the complicated international linkages that have shaped the competitiveness of many countries. Especially in the case of small, open 'catching-up' economies, assessing national competitiveness solely on the basis of the potential of domestic companies, based on local conditions, does not fully reflect their developmental context, which is also driven by the complex networks of international interdependencies. Building upon the generalized double diamond model developed by Moon et al. (2000), this paper explores the extent to which economic relations with international partners and the activities of
\end{abstract}

\footnotetext{
* Ph.D., Full Professor at the Cracow University of Economics, Department of International Economic Relations School

** Cracow University of Economics, Strategic Management Lecturer at the Cologne Business
} 
transnational corporations affect the competitiveness of the Visegrad Group countries, and how this relationship has been changing in the post-accession period. To answer the research problem posed, Eurostat and Global Competitiveness Report data have been gathered to assess the competitiveness variables on both the domestic/national and international levels. It has been shown that integration within the global economy constitutes an essential element of competitiveness for each of the analysed countries.

Keywords: international competitiveness, Visegrad Group countries, Porter's diamond, double diamond model, small open economy

\section{Introduction}

The study of national competitiveness and the search for its sources have not only become a high-priority aspect for policy makers (Lloyd-Reason 2000, p.17) ${ }^{1}$, but has also dominated theoretical considerations in the area of international economics and management (Garelli 2008, p. 30). The popularity of the concept has resulted in a lack of the researchers' congruence in defining national competitiveness ${ }^{2}$, which consequently leads to difficulties in the modelling and measurement of this phenomenon (Olczyk 2008, p. 47).

One of the perspectives on national competitiveness is associated with structural changes within the economy, driven by the efficient utilization of resources (Wysokińska 2001, p.37). Based upon this approach, according to Porter, productivity is the only meaningful measurement of competitiveness (Porte 1990, p.6). This logic has become a cornerstone of Porter's diamond model, one of the most well-known approaches to competitiveness ${ }^{3}$. At its core lies the assumption that successful companies contribute to the establishment of innovative sectors, which in turn stimulate the creation of national competitiveness (Porter 1990). These are the country's conditions that provide

1 In many countries, specialized agencies have been assigned to monitor national competitiveness e.g.: the Presidential Commission on Competitiveness in the USA, the National Competitiveness Council of Ireland, the Asia Competitiveness Institute in Singapore.

${ }^{2}$ A comprehensive overview of the most important Polish and international definitions of national competitiveness can be found in: Misala, 2011, pp. 63-68.

${ }^{3}$ The majority of student textbooks in the area of international strategic management and international management use Porter's diamond as a basic framework capturing locational advantages. 
the context for business activity, constituting a favourable environment for the development of companies capable of competing on the international arena.

However, in the era of trade liberalization, the free movement of production factors across national boundaries, and the increasing role of transnational corporations (Pietrzyk 2009, pp. 20-35), assessing national competitiveness solely on the basis of the potential of domestic companies, based on the local conditions, does not fully reflect role played by the complex networks of international interdependencies.

Based upon the assumption that the competitive position of many 'small open economies' ${ }^{4}$ is contingent upon their ability to exploit the opportunities offered by the development of the global economy as well as upon effective integration within the international division of labour (Castello et al. 1999, p. 45.), proposals to 'internationalize' the diamond model have been suggested. The generalized double diamond model is often considered as one of the most complex extensions (Moon et al. 2000, pp. 111-133).

The impact of integration within the global economy on the development of national competitiveness becomes particularly interesting when reflecting in the economic history of the Visegrad countries since their accession to the European Union. It appears that for these 'catching-up economies', international support (which encompasses not only access to factors of production and target markets, but also as an accelerator of a local competition) has played a key role in the process of modernization of their economies, directly contributing to increased competitiveness of the companies operating in these countries.

In view of the above, this paper aims at answering the two-pronged question: To what extent do the economic relations with international partners and the activities of transnational corporations affect the national competitiveness of the members of the Visegrad Group, and how has this role has been changing for each of these countries in the post-accession period? It is assumed that characteristic data for this period will be data for the years 2004, 2007, 2009 and 2011.

\footnotetext{
${ }^{4}$ In economic theory, a small open economy is defined in the context of perfect competition as a country with a high share of exports in total production, small enough not to affect the world prices, global interest rates or incomes (Grossman, Helpman 1991, p.144; Nolan, Nolan 1991).

${ }^{5}$ The concept of a small open economy is a relative term; there is a general agreement that the solely used criterion of population size does not fully reflect its specificity- therefore the terms: "newly industrialized", "less developed" or "catching-up" country seem to better reflect the most important features of a small open economy (Castello, Ozawa 1999, p. 16).
} 


\section{Porter's diamond model of national competitiveness}

Porter combines aspects of the 'international successes of domestic companies with the development of the whole economy. The concept, presented in 1990 in his book The Competitive Advantage of Nations, associates national competitiveness with the notion of productivity, with regard to which resources are employed. Thus, by raising the level of technological advancement among the companies, it is possible to use the factors of production in a more effective manner. Higher efficiency leads to economic growth and, as a result, produces more wealth and increases living standards (Porter 1990, p. 6).

According to Porter's concept, the competitiveness of the economy is determined by interdependent factors at the microeconomic level, which include: factor conditions, demand conditions, rivalry among the companies, and the existence of supporting industries. The network of relations and interactions between the elements of the system forming a 'diamond' constitutes the context for the business's development. Joined micro-successes create innovative sectors, affecting the competitiveness of the entire country.

Figure 1. Porter's diamond of competitive advantage

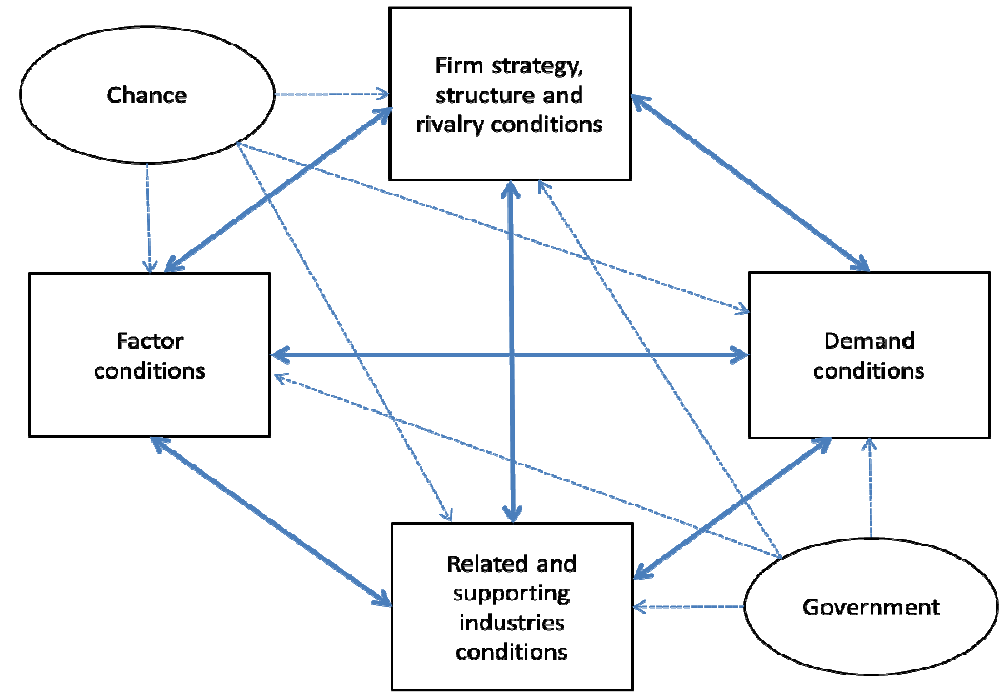

Source: Porter M., 1990, p. 28. 


\section{3. 'Internationalization' of Porter's diamond model}

As emphasized by Moon et al., Porter's model was constructed based on the analysis of world exports' share data for Denmark, Italy, Japan, Singapore, South Korea, Sweden, Switzerland, USA, Great Britain and Germany. In 1990 most of them were seen as developed countries; only Singapore and South Korea could have been considered as 'catching-up' ones. An interesting fact is that Porter, basing his conclusions upon the Diamond model, was positive about the prospective development of Korea; however, he stressed that Singapore would remain a "factor-driven economy" due to the internal constraints, with no chance to reach "a truly advanced status" (Moon et al. 2000, p. 113).

Due to the fact that small open economies often have limited bargaining power in global markets, limited resources and/or a small domestic demand, in principle, according to Porter's model, they do not have good prospects for building a sustainable competitive advantage (Moon et al. 2000, p. 112).

In practice, however, their inclusion into the mainstream global economy gave numerous small open economies a real chance to overcome natural development barriers and allowed them to achieve some remarkable economic successes. Countries in Southeast Asia should be mentioned here (Cho et al. 1998, pp. 5-19), with Singapore being the prime example (Moon et al. 2000, p. 113).

Castello et al. associate these successes with a set of features characteristic for small open economies, which include (Castello at al., pp. 15-16.):

- greater pro-export orientation, especially in the early stages of development;

- higher level of specialization in niche products, together with the progress of industrialization;

- greater involvement in world trade;

- a more homogeneous structure of society, and as a result better relations between the government, corporations and society, which translates into a public-private partnership;

- better ability to adapt to changing external conditions.

The inclusion of the small open economies in the wider circle of economic relations has been supported by the processes of regional economic integration, leading to the formation of regional groupings, and ultimately to the creation of common markets among member countries (Oziewicz 2007, pp. 11-13.)

In view of the above, numerous economists have pointed out the need of "adapt" the diamond model to the development circumstances of the small "catching-up" economies (Dunning 1993; Rugman, D'Cruz 1993, Hodgetts 1993, Cartwright 1993; Bellak 1993, Moon et al. 1998; O'Malley et al. 2000). 
Moon et al. put forward the concept of the "generalized double diamond", in which competitiveness has been defined as: "the capability of firms engaged in value added activities in a specific industry in a particular country to sustain this value added over long periods of time in spite of international competition"(Moon et al. 2000, p. 117). At the same time, it has been stressed that the competitiveness of a small 'catching-up' economy is created:

- by both domestically owned and foreign owned firms acting in the country's territory; thus transnational corporations should not be treated as an additional determinant, but as a force 'extending' the national diamond.

- at an international level through the existence of strong relations between countries in the global economy; sustainability of competitive advantage may require a geographic configuration of activities spanning many countries, where firm specific and location advantages present in several nations are complementary.

In light of the above arguments, the diamond of competitive advantage of a small open economy should be considered in the context of the international diamond', defined as the sum of multilateral economic relations. As shown in Figure 2, when analysing the competitiveness of a small open economy, emphasis should be put on both its internal dimension (described by the national diamond on the basis of the national parameters) and on its external dimension (defined as the sum of interactions with other countries and the impact of the activities of transnational corporations via inbound and outbound FDI).

Figure 2. The generalized double diamond

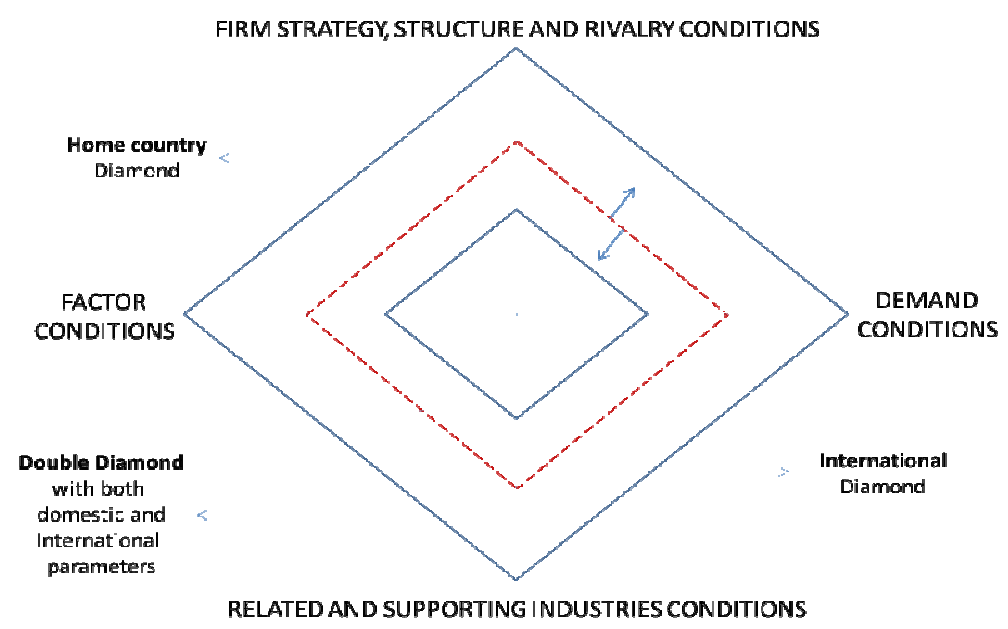

Source: Moon at al., 2000, p. 116. 
The 'double' diamond (diamond of dotted lines) represents the competitiveness of a country "as determined by both domestic and international factors". This structure reflects the fact that, while building a competitive position, smaller countries use not only internal factors, but also utilize the relationships, broadly understood, with the outside world. In this way, the difference in the size of the national diamond and the double diamond shows the extent to which the international context affects the competitiveness of the economy (Moon at al. 2000, pp. 116-117).

\section{Internal and external competitiveness indicators of the Visegrad Group countries}

The Visegrad countries form a heterogeneous group, both in terms of their economic potential and their macroeconomic situations at the onset of the market reforms (Balcerowicz 1995, p. 330). Despite different developmental conditions, as well as an unequal pace and course of political changes, the countries joined forces to reach a common goal: membership in the European Union. Since the beginning of the 1990s, the cooperation between the Visegrad countries has stimulated the modernization of their economies and consequently resulted in an increase in the level of their international competitiveness (Molendowski 2012, p. 15).

In the context of the changes in the international positioning of the Visegrad countries, the goal of this paper is to evaluate the role of external factors in stimulating the competitive evolution of the Group's member states. In order to meet this objective, a comparative analysis was conducted based upon the generalized double diamond model, with division of the sources of competitive advantage into domestic/internal and external ones.

The changing importance of the external and internal factors in shaping the competitiveness of the analysed countries has been illustrated by determining and comparing their 'diamonds' in the following stages of transformation:

- to outline the initial situation: at the time of accession to the EU (2004),

- to outline how much the countries benefited from the accession before the outbreak of the crisis (2007),

- to outline how the global crisis has affected the competitiveness and if it changed the composition of the 'competitiveness building blocks' a year after the outbreak of the crisis (2009),

- to outline the current situation based on the latest available data (2011). 
The analysis was based on the internal and external competitiveness variables for each of the Visegrad countries in each year of the period considered. The difference in the size and shape of the diamonds at the national and international levels helped to estimate the extent to which the inclusion into the new international division of labour contributed to the development of the competitiveness of the analysed economies.

The difficulties in application of this method are related with the problem of selection of the appropriate proxies which could help in the most precise way to estimate elements of the diamond in the national and international perspectives.

The analysis presented in this paper has been based on the proxies suggested by the authors of the original generalized double diamond model (Moon at al., 2000), the analysis of the competitiveness diamonds for Korea and Taiwan by Liu and Hsu (2009), as well as the analysis of the competitiveness of the Romanian economy compared with the EU average by Ban and Postelnicu (2010). The statistical data originates from the Eurostat database and the Global Competitiveness Report ${ }^{6}$.

\subsection{Factor conditions}

Porter made the distinction between basic and advanced factors of production. Since the Visegrad countries belong to the group of 'catching up' economies, basic factors (also in relation to relatively unskilled and low-cost labour) continue to play an important role in the development of these economies (Żmuda 2013, p. 48). For their assessment at the national level, the following indicators have been adopted: activity rate (percentage of the population aged 15-64, both employed and unemployed, who constitute manpower supply), the level of GDP per person employed in the industry, the ratio of labour productivity per hour (with the EU 27 average $=100$ ), and average wage (in Euros per hour).

Advanced factors of production, being a source of innovation and a driving force of technological progress, affect the development of the economy in the long run, constituting the basis for achieving a sustainable competitive advantage (Porter 1990, p.77). To assess the advanced factors on the national

\footnotetext{
${ }^{6}$ Global Competitiveness Report is based on the results of an annual survey conducted among the business leaders in each of the analyzed countries. Answers range from a scale of 1-7, where 1 is the lowest and 7 the highest possible value. For each of the variables used in this paper, the exact question from the Executive Opinion Survey has been presented in the footnotes.
} 
level, the following proxies have been used: the number of employees in $R \& D$ activities (as a percentage of total employment), the level of expenditure on $\mathrm{R} \& \mathrm{D}$ (as a percentage of GDP) and local capacity for innovation ${ }^{7}$.

In an international perspective, it is important to emphasize the role of foreign direct investment, as both inbound and outbound FDI stimulate the competitiveness of the economy. According to the theory of Ozawa, along with the economic development of the country, its FDI structure evolves as the economy goes through the steps of structural change. Starting from the stage of specialization in the area of low-skilled, cheap-labour production, economies evolve to reach the highest level of specialisation based on innovation in the sphere of high technology industries (Ozawa 1992, pp. 27-54).Together with the FDI inflows, advanced factors of production, such as knowledge and technology, are directly and indirectly transferred into the host economy (Lall 2000 , p. 18). Thus to estimate the diamond in the international perspective, the following indicators for basic factors have been chosen: the cumulative value of FDI outflows (as a percentage of GDP) and the value of exports (per capita in Euro). For the advanced factors of production the following proxies were adopted: FDI stock in the economy (as a percentage of GDP), the number of patent applications to the EPO (per million inhabitants), and the extent of technology transfer via FDI $^{8}$.

\subsection{Demand conditions}

As the ability to achieve economies of scale influences the efficiency of a companies' operations, the size and growth rate of domestic demand are key aspects shaping the conditions in which firms operate. GDP per capita (in Euro, in constant prices) and the domestic market size index ${ }^{9}$ were used as indicators of the volume of domestic demand. Due to the small size of three of the analysed economies (Czech Republic, Hungary and Slovakia), the ability to achieve economies of scale depends on the ability to access foreign markets. Thus, the value of exports (as a percentage of GDP) and the foreign market size index ${ }^{10}$ were used as indicators of demand at the international level.

${ }^{7} \mathrm{Q}$ : In your country, how do companies obtain technology? $(1$ = exclusively through licenses or imitating foreign companies; 7 = by conducting formal research and pioneering own products).

${ }^{8}$ Q: To what extent does FDI bring new technologies into your country? $(1=$ not at all, $7=$ FDI is a key source of new technology).

${ }^{9}$ Sum of gross domestic product plus value of imports of goods and services, minus value of exports of goods and services, normalized on 1-7 (best) scale ( GCR hard data).

${ }^{10}$ Value of exports of goods and services, normalized on 1-7 (best) scale (GCR hard data). 
In the classical Keynes' concept of the aggregate domestic demand, only its size was taken into consideration (Keynes 1936). Porter's analysis of national demand is a novum in economics as it introduces the concept of demand 'quality' (Knell 2012, p.12). It is stressed that the more demanding the customers, the higher the sophistication of demand, the bigger the pressure on companies to innovate (Porter 1990, p.89). Moon et al. assume that better education of consumers leads to a higher importance of non-price factors when making a purchase decision (Moon et al. 2000, p.122). Therefore, the proportion of the population with higher education and the index of buyer sophistication ${ }^{11}$ were used as proxies to assess the quality of the national demand. At the international level, the diversification of export markets serves as a proxy for the sophistication of demand. It is assumed that a high exports ratio without the top three destination countries reflects a more diversified and sophisticated international demand (Moon et al. 2000, p. 123).

\subsection{Supporting industries}

Internationally competitive companies do not grow in the vacuum. According to Porter, the creation and the development of competitive companies depends on the existence of high-quality supporting industries. Competitive suppliers and companies within the related industries facilitate innovation and exert pressure to modernize the solutions used in order to meet the high standards of the co-operators. Informal relations between economic entities are of significant importance, as they not only decrease the communication costs but additionally facilitate the exchange of ideas and cooperation in the area of R\&D. In terms of national factors, the following indicators, drafted for the needs of Global Competitiveness Report, were chosen: local supplier quantity ${ }^{12}$ and the state of cluster development ${ }^{13}$. Moon et al. emphasize the importance of transport and telecommunication infrastructure quality. Additionally, the quality of the education system was included into the analysis. To assess the quality of the telecommunication infrastructure and the degree of digitization of the society at the national level, Internet availability has been chosen as a proxy (percentage

\footnotetext{
${ }^{11} \mathrm{Q}$ : In your country, how do buyers make purchasing decisions? (1= based solely on the lowest possible price; $7=$ based on a sophisticated analysis of performance attributes).

${ }^{12} \mathrm{Q}$ : How numerous are local suppliers in your country? (1= largely nonexistent; $7=$ very numerous).

${ }^{13} \mathrm{Q}$ : In your country's economy, how prevalent are well-developed and deep clusters? ( $1=$ nonexistent $;=$ widespread in many fields $)$.
} 
of population aged 15-64 using the Internet regularly $)^{14}$. The infrastructure quality indicator is conveyed by the length of highways (in $\mathrm{km}$ per million of inhabitants) and the quality of support from the education system is measured by the number of science students (per 1,000 citizens aged 20-29).

Moon et al. point out that according to Porter, foreign suppliers hardly ever serve as a substitute for domestic ones (Moon et al. 1998, p. 164). The fact is that in the era of globalized production and increasing internationalization of the supply chain, effective integration within the international division of labour, through backward and forward linkages, may have a strong impact on the competitiveness of companies from smaller and less-developed countries (Moon 2000, p.123). Control of international distribution ${ }^{15}$ serves as a proxy to assess the quality of international linkages. To facilitate international business contacts, it is crucial to have well-developed infrastructure that will enable quick and easy contact between partners from different countries. The following indicators have been chosen to measure this aspect: the cost of international calls (minutes to USA for 1 euro) and the accessibility of the air-transport infrastructure (number to airports serving over 15,000 passengers per year per million citizens). Possibility of establishing contacts and relationships in the international environment has also been enabled by the development of international student exchange programs. To measure the extent which countries internationalize their education systems, the participation of students in the ERASMUS exchange programs was used.

\subsection{Firm strategy, structure and rivalry}

The last element of the diamond is a type of competitive rivalry between companies within a given territory, reflected in their structural organization and executed strategy. It is emphasized that the dynamics and intensity of microrivalry determine the competitiveness of the whole sector (Baum 1996, p. 225).

As the intensity of rivalry constitutes a phenomenon which is difficult to measure, in this area only the results of the survey conducted for the Global Competitiveness Report have been used as proxies. In the national perspective

\footnotetext{
${ }^{14}$ Unlike the original approach of Moon et al., this paper does not take into consideration the number of telephone landlines due to the fact that, as the Eurostat data suggests, in the majority of developed EU countries their number is decreasing as citizens switch to mobile phones.

15 Q: To what extent are international distribution and marketing in your country owned or controlled by domestic companies? ( $1=$ not at all, they take place through foreign companies; $7=$ extensively, they are the primarily owned and controlled by domestic companies).
} 
the following indicators were chosen: intensity of local competition ${ }^{16}$ and the engagement of domestic companies in the international value chain ${ }^{17}$.

Rugman et al. (1993) emphasize that when it comes to small open economies; the presence of international corporations on the local market stimulates competitive rivalry and enhances total productivity. Moon et al., (2000, p. 124) stressed that companies from Singapore and South Korea that were successful globally were more concerned about the competition from international companies than from domestic ones. In this context, the following variables have been adopted: prevalence of trade barriers ${ }^{18}$, the prevalence of foreign ownership ${ }^{19}$ and the incentives for international investors (business impact of rules on FDI) ${ }^{20}$.

The selected competitiveness indicators for the Visegrad Group countries have been compiled in Tables 1-4 of the appendix. In accordance with the methodology used by Moon (2000, pp.124-126) to calculate the competitiveness index for each variable, the maximum value of 100 indicates a country characterised by the highest value, whereas the relative value in percentage is given to the country whose value is lower. If the variable is described by more than one element, each element is given a partial value (in percentage terms) and subsequently the average is calculated.

By way of example: the international demand conditions variable is formed by three elements. In 2004, for the element - geographical export diversification - the maximum value of 100 was given to Hungary. Due to the fact that Slovakia had the highest export to GDP ratio, whereas Poland reported the biggest international market, in these categories the relative values of 83 and 95 were respectively assigned for Hungary. Thus the total value of the variable for Hungary in 2004 was calculated as follows:

\section{$(10083+95) / 3=86$}

Following Moon, it should be emphasized that this analysis does not aim to be a comprehensive presentation of the competitiveness determinants;

\footnotetext{
${ }^{16}$ Q: How would you assess the intensity of competition in the local markets in your country? (1=limited in most industries; $7=$ intense in most industries).

${ }^{17}$ Q: Domestic companies (1=are mainly engaged in raw material processing and production; $7=$ not only produce but also take part in the research, marketing, logistics and customer service).

${ }^{18} \mathrm{Q}$ : In your country, to what extent do tariff and non-tariff barriers limit the ability of imported goods to compete in the domestic market? ( $1=$ strongly limit; $7=$ do not limit).

${ }^{19}$ Q: How prevalent is foreign ownership of companies in your country? (1= rare; $7=$ prevalent).

${ }^{20} \mathrm{Q}$ : To what extent do rules governing foreign direct investment encourage or discourage it? ( $1=$ strongly discourage FDI; $7=$ strongly encourage FDI).
} 
selected variables are used for illustrative purposes only. They can however be regarded as an indicator of the degree of the internationalization of the economy.

\section{Analysis of the competitiveness of the Visegrad Group countries}

In light of the arguments presented above, this part of the paper aims at presenting how the interactions with the international environment enhanced the conditions for development of competitive companies in the Visegrad countries.

Figure 3. National and double diamonds in 2004, 2007, 2009 and 2011
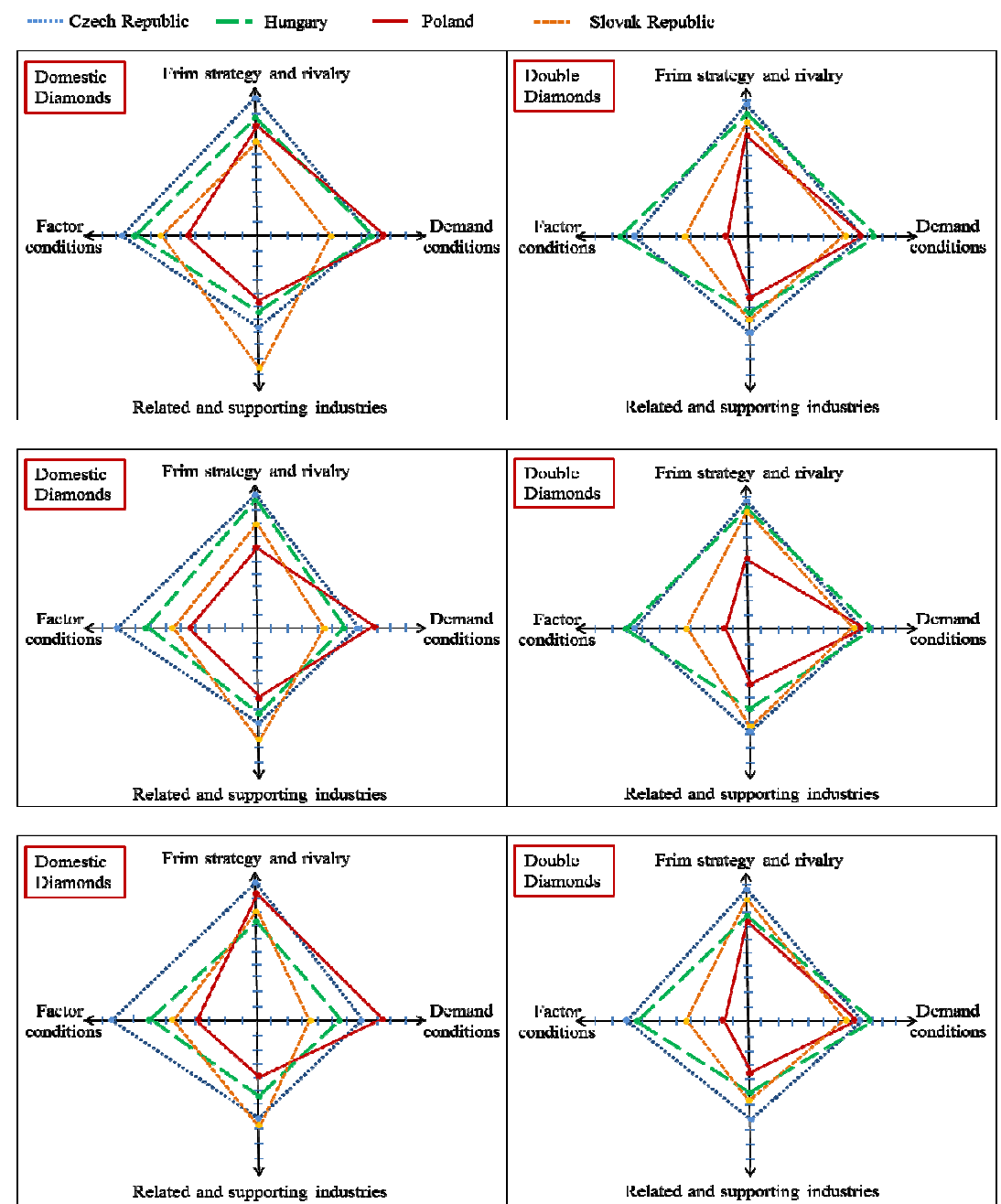


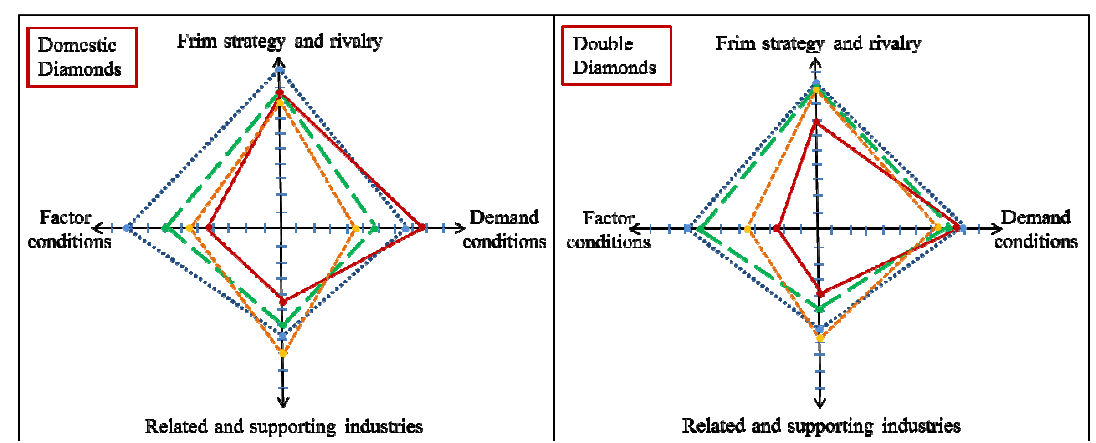

Source: own calculations based on the data in Tables V and VI in the appendix.

Based on the analysis of the diamonds of competitive advantage designed for each of the Visegrad Group countries for the years 2004, 2007, 2009 and 201, as illustrated in Figure 3 above, the following conclusions have been drawn:

\section{With respect to the Czech Republic:}

1) Within the entire analysed period, the Czech Republic has been positioned as a "competitive leader" among the Visegrad countries and was characterised by:

- the best values in the area of factor conditions with the maximum values reported for advanced factors of production for each of the analysed years and a slight improvement in terms of basic factors, mainly due to better productivity and higher activity rate. Attention should be paid to the changes in the labour costs in the Czech Republic. Even though still the highest in the Visegrad Group, the distance separating the Czech Republic from the cheapest country, Slovakia, has decreased;

- a high degree of the development of supporting industries (a slight improvement in the period 2004-2011), mainly due to the development of clusters and improved quality of the higher education system;

- the highest level of rivalry between companies for each of the analysed years

- following the decrease in domestic demand in the crisis years of 20072009, in 2011 the values again reached the 2004 level, which positioned the Czech Republic in second place within the Group in this category, only after the significantly bigger country of Poland.

2) The development of the variable values has been reflected in the largest area of the Czech domestic diamond in comparison to other Visegrad countries throughout the entire analysed period. The Czech Republic was the only country in the Group to enlarge the area of domestic diamond (with slightly deteriorating competitiveness conditions in 2007). 


\section{With respect to Poland:}

1) Values of the Polish domestic competitiveness variables are very diverse, which is reflected in the asymmetric shape of the diamond.

2) The key strengths of Poland, which create a favourable context for the development of local companies, are:

- Demand conditions: Poland clearly differs in this category from the other Visegrad countries due to the size of its domestic market. Moreover, Poland is characterized by a high quality of domestic demand (within the analysed period, Poland reported the highest values for demand sophistication proxies).

- Rivalry: the level of competition between the companies has slightly increased in the period after Poland's EU accession. The general situation in this category has been negatively affected by the systematically deteriorating position of Polish companies in the area of advanced activities within the international value chain. When compared to the companies from the other Visegrad countries, Polish firms were relatively less engaged in activities requiring high qualification;

1) Particularly weak conditions were created by the remaining diamond elements:

- Factor conditions: advanced factors of production constitute the weakest element of the Polish diamond. In the periods between 2004 and 2011, Poland faced a significant decrease in its innovation capability, reflected in lower R\&D spending and a lower employment level in the R\&D sector.

- In the category of supporting industries, having the lowest quality of transport infrastructure and weak cluster development placed Poland in the lowest rank within the Visegrad Group. Positive input from better availability of suppliers was not sufficient to compensate for the weaknesses.

\section{With respect to Hungary:}

1) Hungary recorded the most significant competitive decrease among the Visegrad group countries. In 2004, Hungary was second just behind the Czech Republic whereas in 2011, the Hungarian economy could be described as the one with the least favourable conditions for the development of competitive companies, in particular:

- the most significant decrease can be observed in the size and sophistication of domestic demand, reflecting the deteriorating condition of the country's macroeconomic situation;

- the only element of Hungarian domestic diamond that improved was the supporting industry base;

- in 2007 a significant increase in rivalry was observed; however it deteriorated in 2009, which resulted in Hungary's ranking the lowest 
among all the analysed countries. In 2011, rivalry between companies in Hungary, Slovakia and Poland was at almost the same level;

- a relatively good situation (a slight increase in competitiveness) was observed in the area of basic production factors (Hungary placing second behind the Czech Republic). It is particularly worth mentioning that Hungary had the highest increase of activity rate and the lowest labour costs. This can be attributed to the general deterioration of the dynamics of economic development, which is reflected in the lowest increase in GDP per person employed in the industry sector. Inversely, in the category of advanced production factors, Hungary fell from the second position just behind the leader - the Czech Republic - in 2004, to the very last ranking in 2011. Hence, taking into consideration both the advanced and basic production factors, Hungary's position was constantly declining.

2) the negative development of diamond variables resulted in the weakening of the domestic context in which the companies in Hungary operate. This has been illustrated by the fact that the area of the Hungarian domestic competiveness diamond decreased by $7 \%$ in the period 2004-2011.

\section{With respect to Slovakia:}

1) Within the analysed period, the Slovak economy recorded nearly as many unfavourable results as Hungary:

- the weakest element of the diamond is the size and quality of domestic demand, mainly due to the smallest area and low sophistication of demand. In the period between 2004 and 2011, Slovakia faced a significant decrease in this category, resulting in it having the lowest value of this variable among the Visegrad countries in 2011. The distance between Slovakia and the group leader Poland was constantly increasing;

- supporting industries constitute another problematic area; despite the fact that Slovakia is the leader in this category, it has only a slight advantage over the second ranked country, the Czech Republic;

- although the strongest element of the Slovak diamond is its basic production factors (the highest results among all analysed countries for each year, mainly due to the low remuneration level and the highest work output), poor results in the area of advanced production factors resulted in Slovakia's general ranking of next-to-last (behind Poland) in terms of its competiveness in the area of production factors;

- in the years 2004-2011, a significant increase in the rivalry among Slovak companies can be observed, with the largest jump occurring between 2004-2007. Even though Slovakia's results in the area of rivalry were still the lowest in comparison to the other countries in the group in 2011, the 
positive aspect is that the distance between Slovakia and Poland and Hungary was clearly reduced;

2) As a result of the presented development of the diamond elements Slovakia has faced a strong negative change in its national diamond area (- 6\%). In consequence, Slovakia's results are only better than Hungary and the. The distance to the first-ranked Czech Republic has thereby clearly increased.

When extending the domestic diamonds by the international context, the basis of competitive ability changes. Domestic and double diamonds for each of the Visegrad countries are compared on the Figures 4-7. After factoring in the size and shape of differences reflected in the calculations presented in Tables 1-3, the following conclusions have been drawn:

\section{The Czech Republic (comparison of domestic and double diamonds as presented in Figure 4)}

1) The Czech Republic still has the most competitive economy, but the advantage over Hungary and Slovakia is lower than in the case when only national diamonds are considered. It has to be emphasized that the Czech diamond can be characterised by the greatest symmetry and there are no substantial differences in the values of particular diamond elements.

2) The following elements of the double diamond can help Czech companies to improve their level of competitiveness internationally:

- since 2007, demand conditions, i.e. expanding the demand for Czech products in international markets, is reflected in the increasing export to GDP ratio. It is also worth emphasizing that the Czech Republic managed to diversify export by increased diversification of export destinations;

- in 2004, Czech companies were based on solid ground created by supporting industries; however, in subsequent years, the indicators in this category deteriorated;

3) For the remaining elements of the double diamond, Czech indicators are the highest in the group; however, these values do not exceed the results for the domestic diamond. The variables for the domestic and double diamond fluctuate around the same high values, hence it can be stated that the competitive advantage of the Czech Republic is built on two solid pillars: domestic and international. Therefore, it can be hypothesized that international relations as broadly understood were not the main driving force for the competitiveness of Czech companies.

4) The comparison of the Czech national and double diamond proves this hypothesis correct. In the period between 2004-2011, the area of the domestic diamond grew, which allows for the conclusion that Czech companies rely increasingly on favourable conditions in their own country. 
Figure 4. Domestic and double diamonds for the Czech Republic

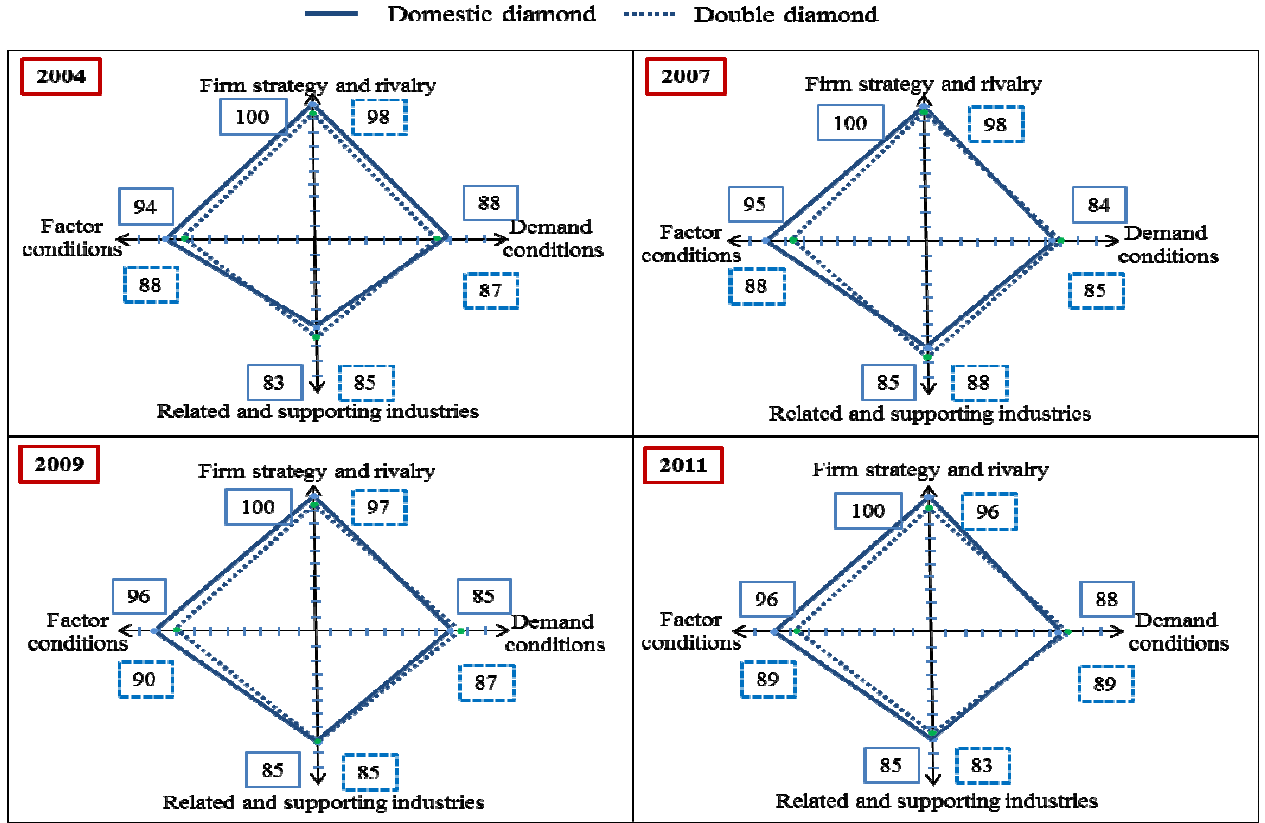

Source: own calculations based on the data in tables V and VI in the appendix.

\section{Poland (comparison of national and double diamonds as presented in Figure 5 )}

1) Demand conditions: Theoretically, Poland, as the biggest country in the Visegrad Group, should depend on engagement in international markets to the lowest extent. However, in this category, compared to the other countries, Poland's results are relatively the best of all double diamond elements; hence it can be concluded that the export engagement of Polish companies constitutes an essential element of their development.

2) Production factors: among all the Visegrad countries, Poland noted the largest improvement in terms of the use of foreign production factors. Particularly worth noting is the transfer of technologies to Poland via FDI and the significant increase in the engagement of Polish companies in outward foreign direct investment, which resulted in reducing the distance between Poland and the first-ranked Czech Republic.

3) Supporting industries: during the analyzed period, Poland showed the worst indicators in this area. However, the high engagement of Polish companies in international distribution control is worth emphasizing. 
4) Rivalry: with the low engagement of foreign companies with foreign capital in the Polish economy and the presence of foreign goods on the domestic market, the level of rivalry is far lower than in the other countries in the group.

Figure 5. Domestic and double diamonds for Poland

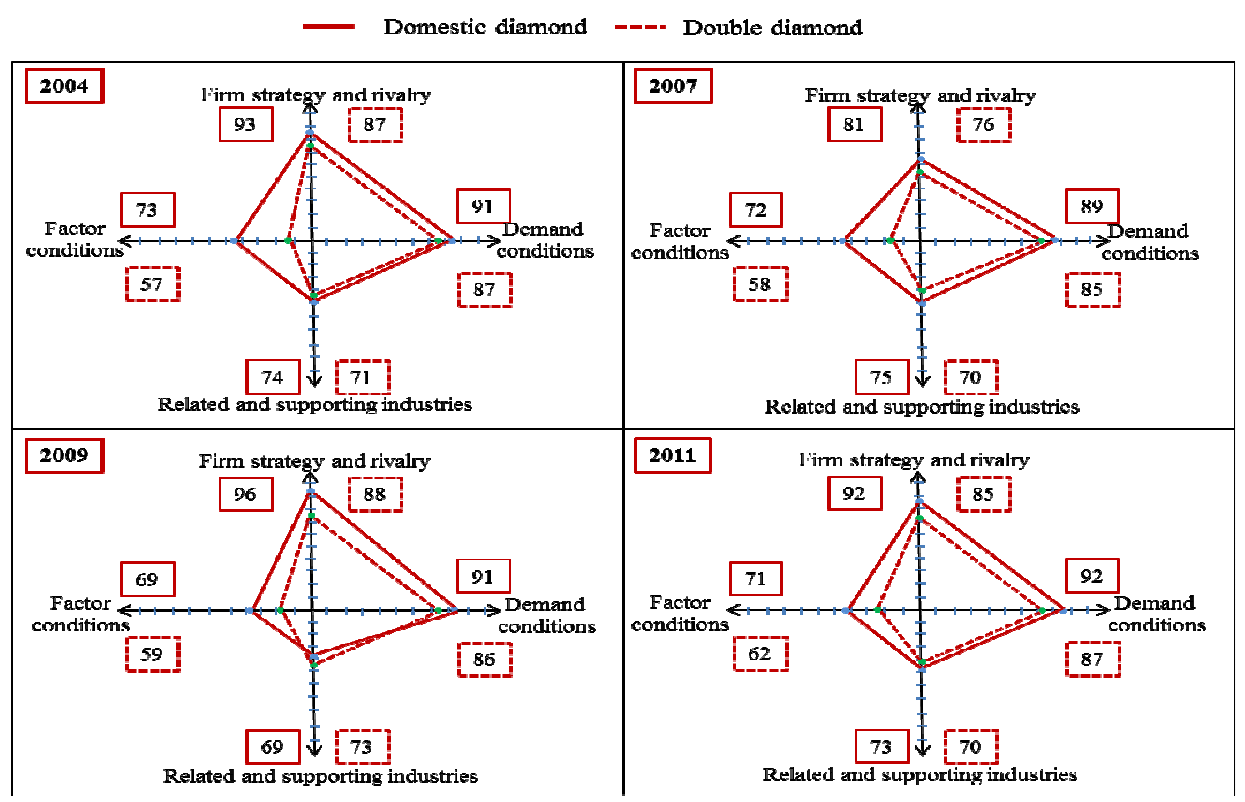

Source: own calculations based on the data in tables V and VI in the appendix.

5) To conclude, the smallest area of the Polish double diamond in each of the analysed years shows that in building their competitive positioning Polish companies rely on international relations only to a low extent. Nevertheless, the distance between Poland and the group leaders is decreasing and the significance of international relations is growing. This is reflected in the decreasing area difference between the domestic and double diamonds. 
Figure 6. Domestic and double diamonds for Hungary

Domestic diamond =--= Double diamond

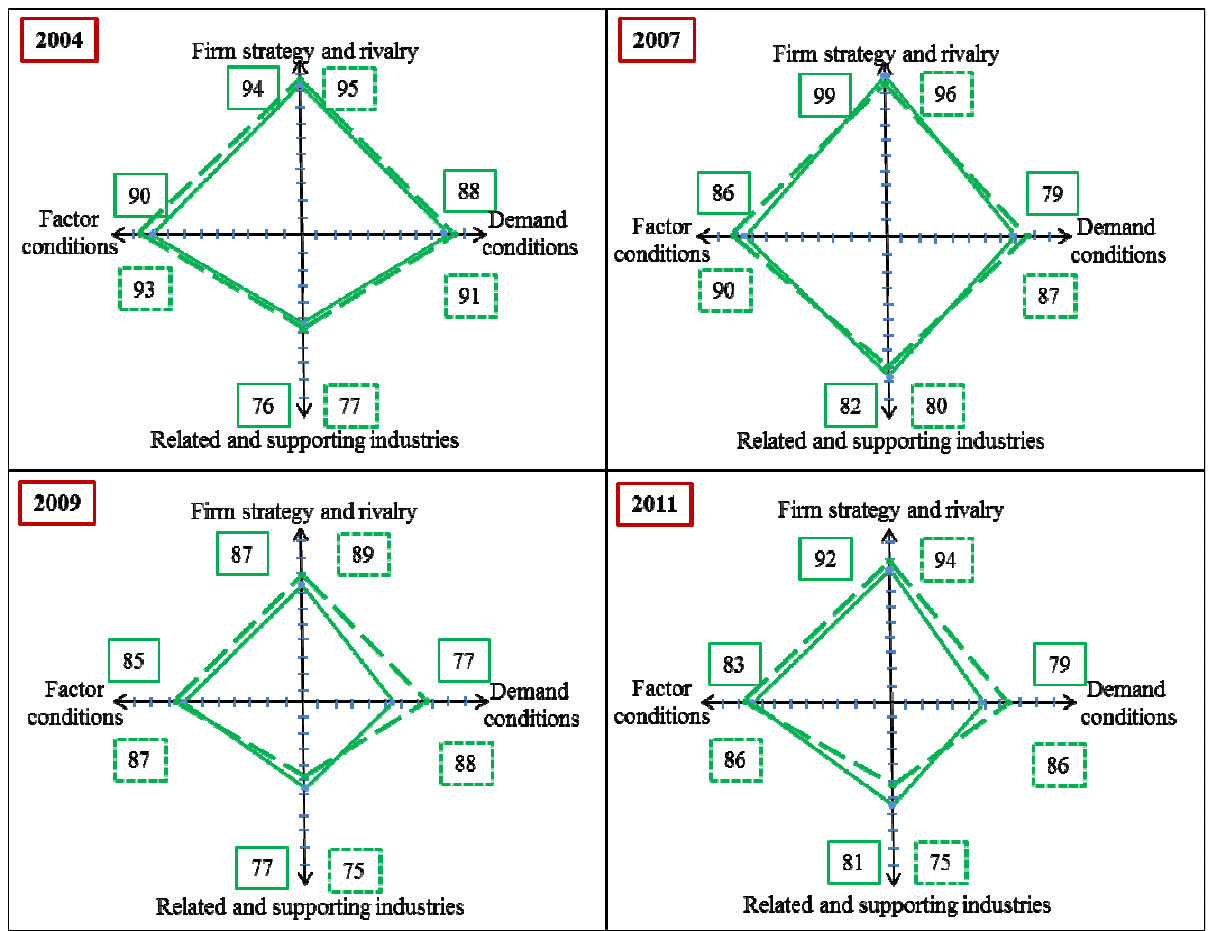

Source: own calculations based on the data in tables V and VI in the appendix.

\section{Hungary (comparison of national and double diamonds as presented in Figure 6)}

1) International interactions significantly 'expanded' the Hungarian domestic diamond of competitive advantage. In 2004, Hungary's double diamond was slightly bigger than the national diamond in each of the variables. At that time, taking into account both domestic and external factors, Hungary was the most competitive country in the Visegrad group.

2) Since 2007, Hungary's level of competitiveness has been gradually decreasing in comparison to the other analysed countries, which resulted in the fact that in 2011 Hungary's double diamond constituted $91 \%$ of the leader's (Czech) diamond.

3) The most significant decrease in Hungary's competitiveness level can be observed in the area of supporting industries and production factors (especially in the area of advanced production factors). Worth emphasizing is the very high activity of Hungarian companies when it comes to 
internationalization of their operations (outward FDI), which could be caused by the need to search for new markets in the face of weak national demand.

4) When it comes to demand conditions, growth was observed in 2004-2009 due to the high volume and large diversification of exports. However, in 2011 there was a significant visible slump, especially in the export level as a percentage of GDP. Nevertheless, access to external markets still constitutes one of the main driving forces of the Hungarian economy.

5) When analyzing the influence of internationalization of the rivalry in the Hungarian market, it is worth noting that, on the one hand, there is a significant increase in the inflow of foreign products and on the other hand, the engagement of international investors is decreasing. This may suggest that the international companies prefer to service the Hungarian market through exports rather than FDI.

\section{Slovakia (comparison of national and double diamonds as presented in Figure 7)}

1) Slovakia's competitiveness is currently based mainly on external factors. Between 2004-2011 Slovakia reduced the distance to the leader, the Czech Republic, and in 2011 moved very close to the level of Hungary.

2) The following external elements are of significant importance for the development of the Slovak companies:

- international demand: due to the small domestic market, Slovak companies rely heavily on export, which is reflected in the highest values of the country's share of export to GDP. As a result, the double diamond 'expands' the national diamond in this category;

- prevalence of foreign-owned companies on the domestic market increases the level of rivalry among all the Visegrad group countries, but Slovakia relies on international companies to the greatest extent (increase in importance by $7 \%$ between $2004-2011$ ), which results in the extension of the domestic diamond in this category also;

3) Slovakia's conditions in the area of supporting industries improved significantly; as a result, the support for international business activity is an essential supplement to the strongest element of the national diamond in the analyzed period. 
Figure 7. Domestic and double diamonds for Slovakia

Domestic diamond ------ Double diamond

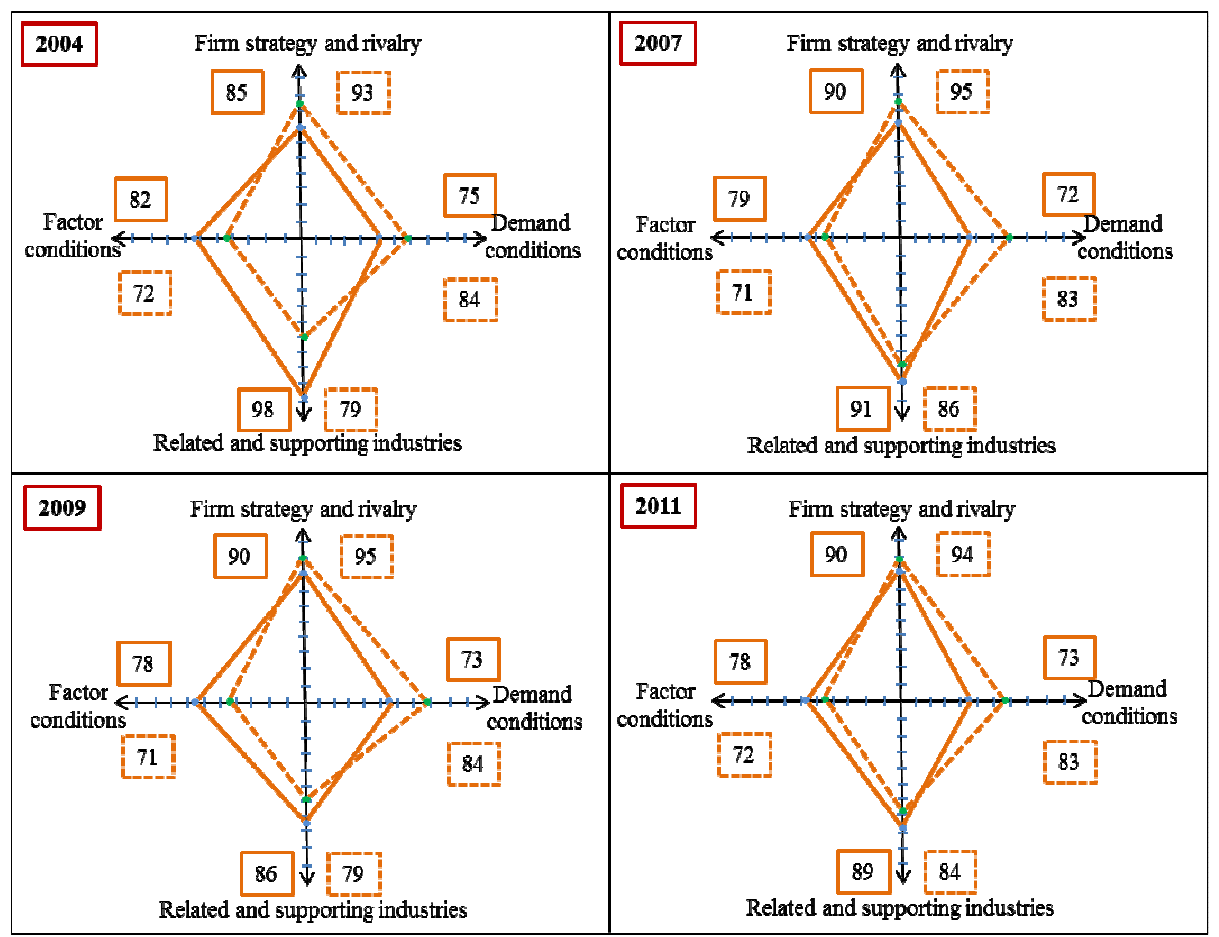

Source: own calculations based on the data in tables V and VI in the appendix.

4) Lack of improvement in the area of use of international factors of production constituted the element which significantly weakened the Slovak competitive advantage. Although it seems that Slovakia has currently moved to a phase strongly driven by FDI inflow, it remains the country with the lowest level of outflowing FDI as compared to other countries in the group. This might be evidence of a very low development level of Slovak companies, which have not yet developed ownership advantages crucial for effective internationalization aimed at making use of international factors of production. The lowest number of patent applications reported by Slovakia to the European Patent Office seems to confirm this fact.

5) Summing up, Slovakia is the country which benefited the most from entering into international economic relations during the analysed period. It is, however, still the country based the most on incoming rather than outgoing internationalization. 
Table 1. The area of domestic diamonds of the Visegrad Group countries

\begin{tabular}{|l|c|c|c|c|c|}
\hline & \multicolumn{5}{|c|}{ Area of domestic diamonds } \\
\hline Countries & $\mathbf{2 0 0 4}$ & $\mathbf{2 0 0 7}$ & $\mathbf{2 0 0 9}$ & $\mathbf{2 0 1 1}$ & Change 2011/2004 \\
\hline Czech Republic & 16.653 & 16.558 & 16.743 & 17.020 & $102 \%$ \\
\hline Poland & 13.694 & 12.558 & 13.200 & 13.448 & $98 \%$ \\
\hline Hungary & 15.130 & 14.933 & 13.284 & 14.013 & $93 \%$ \\
\hline Slovakia & 14.366 & 13.666 & 13.288 & 13.515 & $94 \%$ \\
\hline
\end{tabular}

Source: authors' own calculations on the basis of the data presented in the appendix in Tables I-VI.

Table 2. The area of double diamonds of the Visegrad Group countries

\begin{tabular}{|l|c|c|c|c|c|}
\hline & \multicolumn{5}{|c|}{ Area of double diamonds } \\
\hline Countries & $\mathbf{2 0 0 4}$ & $\mathbf{2 0 0 7}$ & $\mathbf{2 0 0 9}$ & $\mathbf{2 0 1 1}$ & Change 2011/2004 \\
\hline Czech Republic & 16.013 & 16.089 & 16.107 & 15.931 & $99 \%$ \\
\hline Poland & 11.376 & 10.509 & 11.673 & 11.548 & $102 \%$ \\
\hline Hungary & 15.824 & 15.576 & 14.350 & 14.534 & $92 \%$ \\
\hline Slovakia & 13.416 & 13.937 & 13.485 & 13.795 & $103 \%$ \\
\hline
\end{tabular}

Source: authors' own calculations on the basis of the data presented in the appendix in Tables I-VI.

Table 3. The differences in the area of national and double diamonds (in \%)

\begin{tabular}{|l|c|c|c|c|c|c|c|c|}
\hline \multirow{2}{*}{ Countries } & \multicolumn{2}{|c|}{2004} & \multicolumn{2}{c|}{2007} & \multicolumn{2}{c|}{2009} & \multicolumn{2}{c|}{2011} \\
\cline { 2 - 9 } & \multicolumn{9}{|c|}{ DIAMONDS } & do9 \\
\cline { 2 - 9 } & domestic & double & domestic & double & domestic & double & domestic & double \\
\hline $\begin{array}{l}\text { Czech } \\
\text { Republic }\end{array}$ & 100 & 96 & 100 & 97 & 100 & 96 & 100 & 93 \\
\hline Poland & 100 & 80 & 100 & 81 & 100 & 87 & 100 & 84 \\
\hline Hungary & 96 & 100 & 96 & 100 & 93 & 100 & 96 & 100 \\
\hline Slovakia & 100 & 93 & 98 & 100 & 99 & 100 & 98 & 100 \\
\hline
\end{tabular}

Source: authors' own calculations on the basis of the data presented in the appendix in Tables V and VI.

\section{Conclusions}

The results of the conducted analysis prove that integration within the global economy constitutes an essential element of competitiveness for each of the Visegrad Group countries.

For the Czech Republic, which offers the most favourable domestic conditions for establishing businesses and the development of competitive 
companies, its broadly defined interactions with foreign countries and multinational enterprises constitute its second competitiveness pillar.

Since the beginning of a transition process, Hungary has been strongly integrated within the international division of labour, mainly due to significant inflows of foreign direct investment and a high export level. In the time of crisis, which resulted in decreased attractiveness of the Hungarian economy for international investors and deteriorating domestic macroeconomic conditions, the external orientation approach seems to be even more important for the competitiveness of Hungarian companies than in times of prosperity.

Slovakia, as the smallest economy in the Visegrad Group, has benefited the most from the opportunities created by EU accession. A significant improvement in competitiveness, as compared to the other countries, occurred mainly due to the development of international economic relations, which gradually became the main driving force of development for companies operating in Slovakia.

It can be noted that among the analyzed economies, Poland offers the least convenient conditions for the development of competitive companies. However, it has to be emphasized that during the analysed period, the situation gradually improved and the distance between Poland and the group leader, the Czech Republic, was reduced, mainly due to the use of external factors.

In analysing the period shortly after the EU accession (2004-2007), it is worth noting that none of the countries improved their competitiveness when taking into account only domestic conditions. Once the perspective is enlarged by external factors, a slight improvement can be observed for the Czech Republic and a very strong one for Slovakia.

Moreover, interesting conclusions can be drawn in relation to the competitive changes of the Visegrad Group countries during the crisis. When comparing the results from 2007 with 2011, it can be concluded that only in Poland did the context for the development of competitive companies improve both in the domestic and external context. The Czech Republic managed to improve the situation only in the domestic perspective. In the case of the other analysed countries, both external and domestic conditions for the development of economic activity deteriorated: slightly in Slovakia and significantly in Hungary. 


\section{References}

Balcerowicz L. (1995),Wolność i rozwój - ekonomia wolnego rynku, Znak, Kraków

Ban I., Postelnicu C. (2010), Some Empirical Approaches of the Competitiveness' Diamond - the Case of Romanian Economy, 'The Romanian Economic Journal', Vol. XIII, No. 36

Baum, J. A, Korn, H.J. (1996), Competitive dynamics of inter firm rivalry, 'Academy of Management Journal', Vol. 39

Bellak C. (2001), The Austrian investment development path, 'Transnational Corporations', Vol. 10, No. 2

Bellak C., Weiss A. (1993), Extensions of the Porter Diamond Framework, 'Management International Review', Vol. 33

Cartwright W. (1993), Multiple Linked "Diamonds" and the International Competitiveness of Export-Dependent Industries: The New Zealand Experience, 'Management International Review', Vol. 33, No. 2

Castello S., Ozawa T. (1999), Globalization of small economies as a strategic behavior in international business, Garland Publishing, London

Cho, D., Moon H. (1998), A nation's international competitiveness in different stages of economic development, 'Advances in Competitiveness Research', Vol. 6, No. 1

Crowe D., Brennan L. (2001), Aspects Of Competitiveness In A Small Open Economy, Proceedings of 6th Asian-Pacific Decision Sciences Institute (APDSI) Conference, Singapore, National University of Singapore

Dunning J.H, (1993), Internationalizing Porter's Diamond, 'Management International Review', Vol. 33, No. 2

Erasmus Program Statistical Overview 2004/2005, 2007/2008, 2009/2010 and 2010/2011

Eurostat Database, http://epp.eurostat.ec.europa.eu/portal/page/portal/statistics/search_database

Garelli S. (2008), Competitiveness 20 years later [in:] IMD World Competitiveness Yearbook 2008, IMD, Lausanne

Global Competitiveness Report, 2005, 2008, 2010, 2012, World Economic Forum, Geneva

Grossman G., Helpman E. (1991), Innovation and Growth in the Global Economy, MIT Press, Cambridge, MA

Hodgetts R. (1993), Porter's Diamond Framework in a Mexican Context, 'Management International Review', Vol. 33, No. 2

Keynes J. M. (1936) The General Theory of Employment, Interest and Money, Macmillan, London

Knell M. (2012), Demand driven innovation in Economic Thought, UNDERPINN conference materials: Demand, Innovation and Policy, Manchester Institute of Innovation Research, MBS, University of Manchester 
Lall S. (2000), Foreign direct investment, technology development and competitiveness: issues and evidence [in:] Lall S., Urata S. (ed.), Competitiveness, FDI and Technological Activity in East Asia, Edward Elgar, Northampton

Liu D., Hsu H. (2009), An international comparison of empirical generalized double diamond approaches to Taiwan and Korea, 'Competitiveness Review: An International Business Journal', Vol. 19, No. 3

Lloyd-Reason L. (2000), Dimensions of Competitiveness. Issues and Policies, Edward Elgar Publishing, Northampton

Misala J. (2011), Międzynarodowa konkurencyjność gospodarki narodowej, PWE, Warszawa

Molendowski E. (2012), Integracja handlowa $w$ Nowych Państwach Członkowskich: doświadczenie i wnioski dla innych krajów Europy Środkowo-Wschodniej, Difin, Kraków

Moon H., Rugman A., Verbeke A. (2000), Extended Model: The Generalized Double Diamond Model [in:] Cho D., Moon H., (ed.) From Adam Smith to Michael Porter, 'Asia-Pacific Business Series', Vol. 2, World Scientific, Singapore

Moon, H, Rugman A., Verbeke A. (1998), A generalized double diamond approach to the international competitiveness of Korea and Singapore, 'International Business Review', Vol. 7

Nolan S., Nolan D. (1991), Economic Growth: Theory and Analysis [in:] O'Hagan J.W., The Economy of Ireland: Policy and Performance of small European country, IMI, Dublin

Olczyk M. (2008), Konkurencyjność. Teoria i praktyka, CeDeWu, Warszawa

O'Malley E., Van Egeraat C. (2000), Industry clusters and Irish Indigenous Manufacturing: Limits of the Porter's View, 'The Economic and Social Review', Vol. 31, No. 1

Ozawa T. (1992), Foreign direct investment and economic development, 'Transnational Corporations', Vol. 1, No. 1

Oziewicz E. (2007), Dylematy rozwoju gospodarczego krajów Azji Południowo-Wschodniej na tle procesów globalizacyjnych, Wydawnictwo Naukowe Uniwersytetu Gdańskiego, Gdańsk

Pietrzyk I. (2009), Globalizacja i regionalizacja gospodarki światowej [in:] Miklaszewski M. (ed.), Gospodarka światowa w warunkach globalizacji i regionalizacji rynków, Difin, Warszawa

Porter M.E. (1990), The Competitive Advantage of Nations, Macmillan Press, New York

Reinert E. (2001), Competitiveness and its predecessors - a 500 year across national perspective, 'Structural Change and Economic Dynamics', Vol. 6

Rugman A.M., D’Cruz J.R (1993), Double Diamond" Model of International Competitiveness: The Canadian Experience, 'Management International Review', Vol. 33, No. 2

Structure of Earnings Survey 2002, 2006, 2010, European Commission

Wysokińska Z. (2001), Konkurencyjność w międzynarodowym i globalnym handlu technologiami, Wydawnictwo Naukowe PWN, Warszawa 
Żmuda M. (2013), Comparative analysis of international competitiveness of the Czech and Slovakian economies: the empirical generalized double diamond approach [in:] Jabłoński Ł., Gavriletea M. (ed.), Selected issues of economic modernization: A Central-East European Perspective, Kraków

\section{APPENDIX}

Table I. Variables for the assessment of the factors of production at the domestic and international levels for Poland, Hungary, Czech Republic and Slovakia

\begin{tabular}{|c|c|c|c|c|c|}
\hline Variables & Year & PL & HU & $\mathbf{C Z}$ & SK \\
\hline \multicolumn{6}{|l|}{$\begin{array}{l}\text { DOMESTIC DIAMOND } \\
\text { Basic factors of production }\end{array}$} \\
\hline \multirow{4}{*}{$\begin{array}{l}\text { Activity rate } \\
\text { (\% of the population aged 15- } \\
64, \text { both employed and } \\
\text { unemployed, who constitute } \\
\text { manpower supply) }\end{array}$} & 2004 & 64.0 & 60.5 & 70.0 & 69.7 \\
\hline & 2007 & 63.2 & 61.9 & 69.9 & 68.3 \\
\hline & 2009 & 64.7 & 61.6 & 70.9 & 68.4 \\
\hline & 2011 & 66.1 & 62.7 & 70.5 & 68.9 \\
\hline \multirow{4}{*}{$\begin{array}{l}\text { GDP per person employed in } \\
\text { the industry }(€)\end{array}$} & 2004 & 51.000 & 62.270 & 49.290 & 48.930 \\
\hline & 2007 & 66.410 & 75.980 & 67.890 & 74.270 \\
\hline & 2009 & 63.600 & 75.100 & 76.200 & 87.400 \\
\hline & 2011 & 75.840 & 82.270 & 85.660 & 98.100 \\
\hline \multirow{4}{*}{$\begin{array}{l}\text { Labour productivity per hour } \\
(\text { EU } 27 \text { average }=100)\end{array}$} & 2004 & 49.9 & 56.6 & 67.2 & 63.5 \\
\hline & 2007 & 50.1 & 56.5 & 71.1 & 71.3 \\
\hline & 2009 & 52.5 & 60.9 & 70.3 & 74 \\
\hline & 2011 & 55.7 & 59.9 & 66.8 & 73.7 \\
\hline \multirow{4}{*}{ Avarage wage per hour $(€)$} & $2004 *$ & 3.18 & 2.51 & 2.82 & 2.08 \\
\hline & $2007 *$ & 4.13 & 3.42 & 4.25 & 3.15 \\
\hline & $2009^{*}$ & 5.11 & 4.59 & 5.25 & 4.74 \\
\hline & $2011^{*}$ & 5.11 & 4.59 & 5.25 & 4.74 \\
\hline \multicolumn{6}{|l|}{ Advanced factors of production } \\
\hline \multirow{4}{*}{$\begin{array}{l}\text { Number of employees in } \\
\text { R\&D activities } \\
\text { (\% of total employment) }\end{array}$} & 2004 & 0.75 & 1.19 & 1.18 & 0.84 \\
\hline & 2007 & 0.72 & 1.17 & 1.41 & 0.88 \\
\hline & 2009 & 0.7 & 1.25 & 1.43 & 0.94 \\
\hline & 2011 & 0.74 & 1.27 & 1.57 & 1.05 \\
\hline
\end{tabular}




\begin{tabular}{|c|c|c|c|c|c|}
\hline \multirow{4}{*}{$\begin{array}{l}\text { R\&D expenditure level } \\
(\% \text { GDP })\end{array}$} & 2004 & 0.56 & 0.88 & 1.20 & 0.51 \\
\hline & 2007 & 0.57 & 0.98 & 1.48 & 0.46 \\
\hline & 2009 & 0.67 & 1.17 & 1.47 & 0.48 \\
\hline & 2011 & 0.77 & 1.21 & 1.84 & 0.68 \\
\hline \multirow{4}{*}{ Local capacity of innovation } & 2004 & 3.5 & 3.7 & 3.7 & 3.7 \\
\hline & 2007 & 4.1 & 4.1 & 4.3 & 3.5 \\
\hline & 2009 & 3.1 & 3.3 & 4.2 & 3.1 \\
\hline & 2011 & 3.3 & 3.4 & 4.0 & 2.8 \\
\hline \multicolumn{6}{|l|}{$\begin{array}{l}\text { INTERNATIONAL DIAMOND } \\
\text { Basic factors of production }\end{array}$} \\
\hline \multirow{4}{*}{$\begin{array}{l}\text { Value of exports } \\
\text { (per capita, } € \text { ) }\end{array}$} & 2004 & 1.580 & 4.416 & 5.431 & 4.148 \\
\hline & 2007 & 2.682 & 6.915 & 8.689 & 7.916 \\
\hline & 2009 & 2.566 & 5.933 & 7.737 & 7.429 \\
\hline & 2011 & 3.494 & 8.073 & 11.116 & 10.566 \\
\hline \multirow{4}{*}{$\begin{array}{l}\text { FDI outflows } \\
\text { (\% GDP) }\end{array}$} & 2004 & 1.2 & 5.4 & 3.0 & 1.8 \\
\hline & 2007 & 4.6 & 11.9 & 4.4 & 2.3 \\
\hline & 2009 & 6.6 & 14.5 & 7.3 & 3.5 \\
\hline & 2011 & 10.3 & 18.4 & 6.6 & 4.7 \\
\hline \multicolumn{6}{|l|}{ Advanced factors of production } \\
\hline \multirow{4}{*}{$\begin{array}{l}\text { Number of patent } \\
\text { applications to the EPO } \\
\text { (per million inhabitants) }\end{array}$} & 2004 & 3.3 & 15 & 11 & 3.8 \\
\hline & 2007 & 5.2 & 18.5 & 17.7 & 6.8 \\
\hline & 2009 & 6.9 & 19.2 & 22.9 & 6.4 \\
\hline & 2011 & 8 & 20.2 & 25.5 & 6 \\
\hline \multirow{4}{*}{$\begin{array}{l}\text { FDI inflows } \\
\text { (\% GDP) }\end{array}$} & 2004 & 31.1 & 55.9 & 45.8 & 47.3 \\
\hline & 2007 & 38.8 & 65.3 & 57.9 & 53.0 \\
\hline & 2009 & 41.5 & 74.7 & 61.7 & 58.1 \\
\hline & 2011 & 41.1 & 64.1 & 60.3 & 57.4 \\
\hline \multirow{4}{*}{$\begin{array}{l}\text { Extent of technology } \\
\text { transfer via FDI }\end{array}$} & 2004 & 5.2 & 5.6 & 5.6 & 5.6 \\
\hline & 2007 & 4.6 & 5.5 & 5.8 & 6.0 \\
\hline & 2009 & 5.1 & 5.2 & 5.4 & 5.9 \\
\hline & 2011 & 5.0 & 5.4 & 5.3 & 5.5 \\
\hline
\end{tabular}

*Structure of Earnings Survey 2002, 2006, 2010 (European Commission) publishes data from the member countries every four years. For the purpose of this analysis for the year 2004 the data from the 2002 report has been used, for 2007 from 2006 and for 2009 and 2011 from 2010.

Source: authors' own calculation based on Eurostat database available online under: http://epp.eurostat.ec.europa.eu/portal/page/portal/statistics/search_database. 
Table II. Variables for the assessment of the factor conditions at the domestic and international levels for Poland, Hungary, Czech Republic and Slovakia

\begin{tabular}{|c|c|c|c|c|c|}
\hline Variables & Year & PL & HU & $\mathbf{C Z}$ & SK \\
\hline \multicolumn{6}{|l|}{ DOMESTIC DIAMOND } \\
\hline$\underline{\text { Demand size }}$ & 2004 & 6,200 & 8,400 & 9,600 & 6,700 \\
\hline \multirow[t]{4}{*}{ GDP per capita (€, constant prices) } & 2007 & 7,300 & 9,200 & 11,500 & 8,500 \\
\hline & 2009 & 7,800 & 8,700 & 11,100 & 8,600 \\
\hline & 2011 & 8,300 & 9,000 & 11,600 & 9,200 \\
\hline & 2004 & 4.8 & 4.0 & 4.2 & 3.6 \\
\hline \multirow{3}{*}{ Domestic market size index } & 2007 & 4.8 & 4.0 & 4.2 & 3.6 \\
\hline & 2009 & 4.9 & 4.0 & 4.2 & 3.7 \\
\hline & 2011 & 4.9 & 3.9 & 4.2 & 3.7 \\
\hline \multicolumn{6}{|l|}{ Demand sophistication } \\
\hline \multirow{4}{*}{$\begin{array}{l}\text { Tertiary education level } \\
(\% \text { of population aged } 30-34)\end{array}$} & 2004 & 20.4 & 18.5 & 12.7 & 12.9 \\
\hline & 2007 & 27 & 20.1 & 13.3 & 14.8 \\
\hline & 2009 & 32.8 & 23.9 & 17.5 & 17.6 \\
\hline & 2011 & 36.9 & 28.1 & 23.8 & 23.4 \\
\hline \multirow{4}{*}{ Buyer sophistication } & 2004 & 3.8 & 3.5 & 3.9 & 3.6 \\
\hline & 2007 & 4.0 & 3.5 & 4.4 & 3.6 \\
\hline & 2009 & 3.9 & 3.1 & 4.1 & 3.4 \\
\hline & 2011 & 3.5 & 2.9 & 3.6 & 2.7 \\
\hline \multicolumn{6}{|l|}{$\begin{array}{l}\text { INTERNATIONAL DIAMONDS } \\
\text { Demand size }\end{array}$} \\
\hline \multirow{4}{*}{ Value of exports (\% GDP) } & 2004 & 29.5 & 54.4 & 52.6 & 65.6 \\
\hline & 2007 & 32.9 & 70 & 57.8 & 77.9 \\
\hline & 2009 & 31.5 & 65.1 & 57 & 64 \\
\hline & 2011 & 36,4 & 71.6 & 74.6 & 82.4 \\
\hline \multirow{4}{*}{ Foreign market size } & 2004 & 5.5 & 5.2 & 5.3 & 4.8 \\
\hline & 2007 & 5.5 & 5.2 & 5.3 & 4.8 \\
\hline & 2009 & 5.6 & 5.3 & 5.5 & 5.1 \\
\hline & 2011 & 5.6 & 5.2 & 5.4 & 4.9 \\
\hline \multicolumn{6}{|l|}{ Demand sophistication } \\
\hline \multirow{4}{*}{$\begin{array}{l}\text { Diversification of export markets } \\
\text { (\% exports without top three destination } \\
\text { countries) }\end{array}$} & 2004 & 60 & 59.7 & 49.7 & 52.5 \\
\hline & 2007 & 62.9 & 64.1 & 54.7 & 59.5 \\
\hline & 2009 & 63.4 & 66.3 & 53 & 60.6 \\
\hline & 2011 & 63 & 63.2 & 52.8 & 58.1 \\
\hline
\end{tabular}

Source: authors' own calculation based on Eurostat database available online under: http://epp.eurostat.ec.europa.eu/portal/page/portal/statistics/search_database 
Table III. Variables for the assessment of the supporting industries at the domestic and international levels for Poland, Hungary, Czech Republic and Slovakia

\begin{tabular}{|c|c|c|c|c|c|}
\hline Variables & Year & PL & HU & $\mathbf{C Z}$ & SK \\
\hline \multicolumn{6}{|l|}{ DOMESTIC DIAMOND } \\
\hline \multirow{4}{*}{ Local supplier quantity } & 2004 & 4.7 & 4.8 & 5.2 & 4.9 \\
\hline & 2007 & 4.4 & 4.7 & 5.5 & 5.1 \\
\hline & 2009 & 5.3 & 4.7 & 5.7 & 5.1 \\
\hline & 2011 & 5.5 & 4.6 & 5.3 & 5.0 \\
\hline \multirow{4}{*}{ State of cluster development } & 2004 & 3.2 & 2.7 & 2.7 & 3.1 \\
\hline & 2007 & 3.2 & 2.7 & 2.7 & 3.1 \\
\hline & 2009 & 2.9 & 2.9 & 4.1 & 3.4 \\
\hline & 2011 & 2.7 & 3.1 & 3.9 & 3.6 \\
\hline \multicolumn{6}{|l|}{ Telcommunication infrastructure } \\
\hline \multirow{4}{*}{$\begin{array}{l}\text { Internet availability ( } \% \text { of population } \\
\text { aged } 16-74 \text { using the Internet regularly) }\end{array}$} & 2004 & 22 & 21 & 25 & 40 \\
\hline & 2007 & 39 & 49 & 42 & 51 \\
\hline & 2009 & 52 & 57 & 54 & 66 \\
\hline & 2011 & 58 & 66 & 63 & 72 \\
\hline \multicolumn{6}{|l|}{ Education system } \\
\hline \multirow{4}{*}{$\begin{array}{l}\text { Science students } \\
\text { (per } 1,000 \text { citizens aged 20-29) }\end{array}$} & 2004 & 9.4 & 5.1 & 7.4 & 9.2 \\
\hline & 2007 & 13.9 & 6.4 & 12 & 11.9 \\
\hline & 2009 & 14.3 & 7.5 & 15.3 & 17.5 \\
\hline & 2011 & $15.8 *$ & $8.3^{*}$ & $16.5 *$ & 17.6 \\
\hline \multicolumn{6}{|l|}{ Transport infrastucture } \\
\hline \multirow{4}{*}{$\begin{array}{l}\text { Highway accessibility } \\
\text { (km per million of inhabitants) }\end{array}$} & 2004 & 14 & 56 & 53 & 59 \\
\hline & 2007 & 17 & 85 & 64 & 68 \\
\hline & 2009 & 22 & 127 & 70 & 72 \\
\hline & 2010 & 22 & 127 & 70 & 77 \\
\hline \multicolumn{6}{|l|}{ INTERNATIONAL DIAMOND } \\
\hline \multicolumn{6}{|c|}{ Development of the formal and informal relations between economic entities } \\
\hline \multirow{4}{*}{ Control of intrenational distribution } & 2004 & 3.9 & 3.9 & 3.5 & 3.6 \\
\hline & 2007 & 3.8 & 3.6 & 3.7 & 3.7 \\
\hline & 2009 & 4.4 & 3.6 & 3.7 & 3.7 \\
\hline & 2011 & 3.9 & 3.7 & 3.6 & 3.4 \\
\hline \multicolumn{6}{|l|}{ Telecommunication infrastructure } \\
\hline \multirow{4}{*}{$\begin{array}{l}\text { Cost of international calls } \\
\text { (minutes to USA for } 1 \text { Euro) }\end{array}$} & 2004 & 2.69 & 4.17 & 2.39 & 2.64 \\
\hline & 2007 & 2.66 & 4.35 & 4.31 & 6.49 \\
\hline & 2009 & 8.06 & 4.17 & 4.69 & 6.49 \\
\hline & 2011 & 8.06 & 4.17 & 4.27 & 13.33 \\
\hline
\end{tabular}




\begin{tabular}{|lccccc|}
\hline Education system & 2004 & 0.02 & 0.03 & 0.08 & 0.03 \\
ERASMUS exchange program & 2007 & 0.6 & 0.87 & 1.54 & 0.78 \\
participation & 2009 & 0.69 & 1.04 & 1.43 & 0.92 \\
(\% of total students) & 2011 & 0.66 & 1.07 & 1.47 & 0.52 \\
& & & & & \\
Transport infrastucture & 2004 & 0.31 & 0.1 & 0.29 & 1.49 \\
Accessibility of air-transport & 2007 & 0.24 & 0.3 & 0.39 & 1.11 \\
infrastructure & 2009 & 0.26 & 0.3 & 0.48 & 1.11 \\
(airports per 1 million of inhabitants) & 2011 & 0.26 & 0.3 & 0.48 & 1.11 \\
\hline
\end{tabular}

Source: authors' own calculation based on the Erasmus Program Statistical Overview 2004/2005, 2007/2008, 2009/2010 and 2010/2011as well as Eurostat database $* 2010$ data.

Table IV. Variables for the assessment of firm strategy and rivalry at the domestic and international levels for Poland, Hungary, Czech Republic and Slovakia

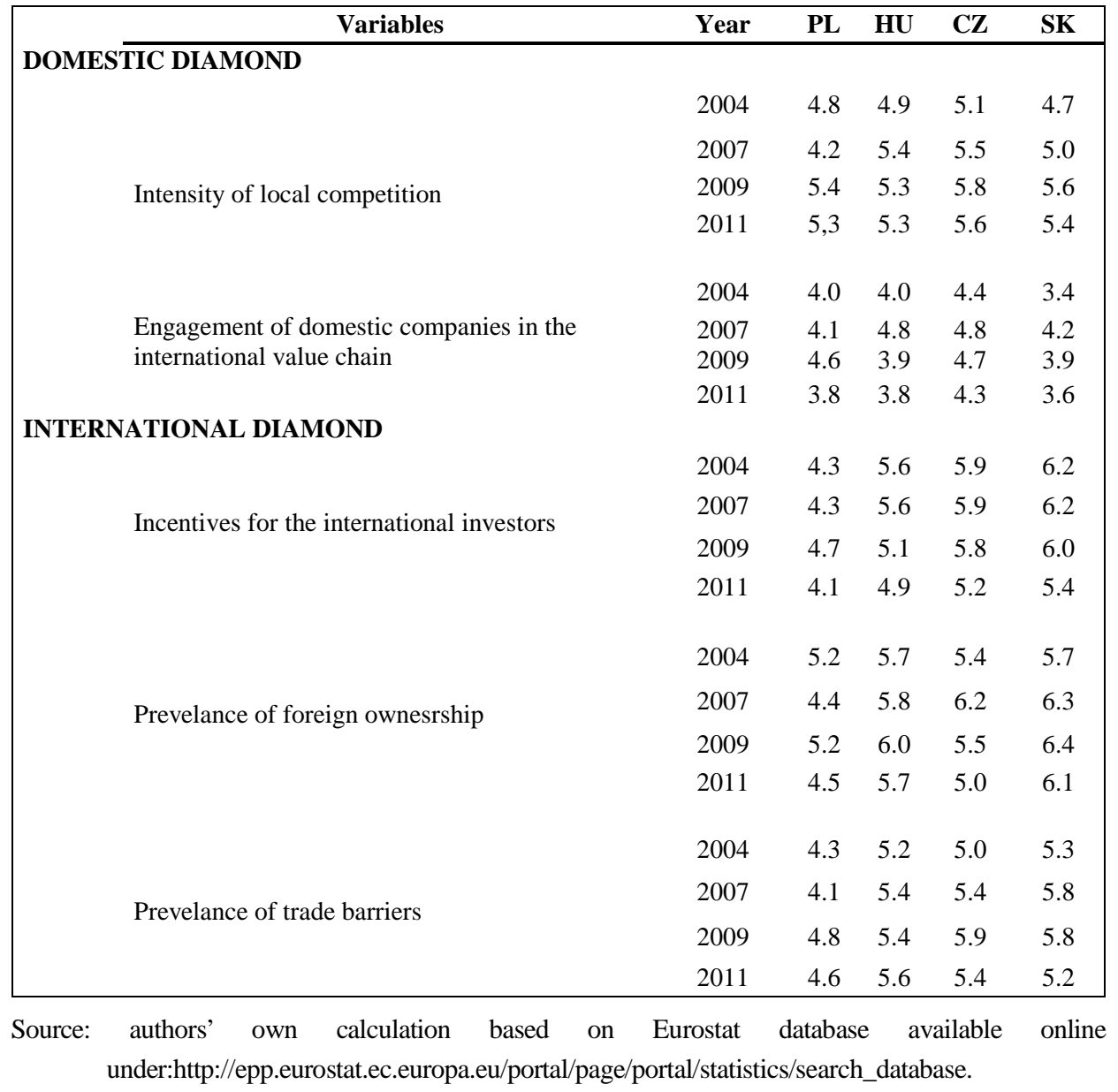


Table V. Competitiveness index of the Visegrad countries for the years: 2004 and 2007

\begin{tabular}{|lccccccccc|}
\hline & \multicolumn{2}{c}{ Poland } & \multicolumn{2}{c}{ Hungary } & Czech Republic & \multicolumn{2}{c|}{$\begin{array}{c}\text { Slovak } \\
\text { Republic }\end{array}$} \\
\cline { 2 - 9 } & $\mathbf{2 0 0 4}$ & $\mathbf{2 0 0 7}$ & $\mathbf{2 0 0 4}$ & $\mathbf{2 0 0 7}$ & $\mathbf{2 0 0 4}$ & $\mathbf{2 0 0 7}$ & $\mathbf{2 0 0 4}$ & $\mathbf{2 0 0 7}$ \\
FACTOR CONDITIONS & & & & & & & & \\
Domestic diamond & 73 & 72 & 90 & 86 & 94 & 95 & 82 & 79 \\
International diamond & 41 & 45 & 95 & 94 & 82 & 81 & 62 & 64 \\
Double diamond & 57 & 58 & 93 & 90 & 88 & 88 & 72 & 71 \\
DEMAND CONDITIONS & & & & & & & & \\
Domestic diamond & 91 & 89 & 88 & 79 & 88 & 84 & 75 & 72 \\
International diamond & 82 & 80 & 93 & 95 & 86 & 85 & 92 & 93 \\
Double diamond & 87 & 85 & 91 & 87 & 87 & 85 & 84 & 83 \\
& & & & & & & & \\
SUPPORTING INDUSTRIES & & & & & & & \\
Domestic diamond & 74 & 75 & 76 & 82 & 83 & 85 & 98 & 91 \\
International diamond & 68 & 64 & 77 & 77 & 87 & 91 & 59 & 81 \\
Double diamond & 71 & 70 & 77 & 80 & 85 & 88 & 79 & 84 \\
STRATEGY AND RIVALRYyyyyyyyyyyyyyy & & & & & & & & \\
Domestic diamond & 93 & 81 & 94 & 99 & 100 & 100 & 85 & 90 \\
International diamond & 80 & 70 & 96 & 92 & 95 & 95 & 100 & 100 \\
Double diamond & 87 & 76 & 95 & 96 & 98 & 98 & 93 & 94 \\
\hline
\end{tabular}

Source: authors' own calculation based on data in Tables I-IV.

Table VI. Competitiveness index of the Visegrad countries for the years: 2009 and 2011

\begin{tabular}{|lccccccccc|}
\hline & \multicolumn{2}{c}{ Poland } & \multicolumn{2}{c}{ Hungary } & \multicolumn{2}{c}{$\begin{array}{c}\text { Czech } \\
\text { Republic }\end{array}$} & \multicolumn{2}{c|}{$\begin{array}{c}\text { Slovak } \\
\text { Republic }\end{array}$} \\
\cline { 2 - 9 } & $\mathbf{2 0 0 9}$ & $\mathbf{2 0 1 1}$ & $\mathbf{2 0 0 9}$ & $\mathbf{2 0 1 1}$ & $\mathbf{2 0 0 9}$ & $\mathbf{2 0 1 1}$ & $\mathbf{2 0 0 9}$ & $\mathbf{2 0 1 1}$ \\
FACTOR CONDITIONS & & & & & & & & \\
Doemstic diamond & 69 & 71 & 85 & 83 & 96 & 96 & 78 & 78 \\
International diamond & 49 & 53 & 90 & 89 & 83 & 82 & 64 & 66 \\
Double diamond & 59 & 62 & 87 & 86 & 90 & 89 & 71 & 72 \\
DEMAND CONDITIONS & & & & & & & & \\
Domestic diamond & 91 & 92 & 77 & 79 & 85 & 88 & 73 & 73 \\
International diamond & 81 & 81 & 98 & 93 & 88 & 90 & 94 & 93 \\
Double diamond & 86 & 87 & 88 & 86 & 87 & 89 & 84 & 83 \\
SUPPORTING INDUSTRIES & & & & & & & \\
Domestic diamond & 69 & 73 & 77 & 81 & 85 & 85 & 86 & 89 \\
International diamond & 78 & 67 & 72 & 69 & 86 & 81 & 72 & 78 \\
Double diamond & 73 & 70 & 75 & 75 & 85 & 83 & 79 & 84 \\
\hline
\end{tabular}




\begin{tabular}{|lrrrrrrrr|}
\hline \multicolumn{2}{l}{ STRATEGY AND RIVALRY } & & & & & & & \\
Domestic diaomnd & 96 & 92 & 87 & 92 & 100 & 100 & 90 & 90 \\
International diamond & 80 & 77 & 90 & 95 & 94 & 91 & 99 & 98 \\
Double diaomnd & 88 & 85 & 89 & 94 & 97 & 96 & 95 & 94 \\
\hline
\end{tabular}

Source: authors' own calculation based on data in Tables I-IV.

\section{Streszczenie}

\section{ZMIANY KONKURENCYJNOŚCI KRAJÓW GRUPY WYSZEHRADZKIEJ PO \\ AKCESJI DO UNII EUROPEJSKIEJ: ANALIZA PORÓWNAWCZA W OPARCIU O UOGÓLNIONY MODEL PODWÓJNEGO DIAMENTU PRZEWAG KONKURENCYJNYCH}

Międzynarodowa konkurencyjność gospodarki narodowej to zagadnienie, które wybudza wiele kontrowersji. W najszerszej perspektywie: to „wspótczesne” ujęcie fundamentalnych problemów rozwoju gospodarczego, osadzone w realiach globalizacji (Reinert, 2001, s. 23-42). Oznacza to, że sity napedzające rozwój gospodarki globalnej: liberalizacja handlu międzynarodowego, działalność inwestycyjna korporacji transnarodowych oraz zacieśnianie wspótpracy gospodarczej $w$ ramach regionalnych ugrupowań integracyjnych, powinny zostać uwzględnione w modelu konkurencyjności. Jedno z najpopularniejszych wielowymiarowych ujęć: diament przewag konkurencyjnych Portera skupia się na źródłach konkurencyjności przedsiębiorstw w ramach poszczególnych gatęzi przemystu. Poprzez podnoszenie stopnia zaawansowania technologicznego firm, poprawia się produktywność czynników wytwórczych, co w efekcie przyczynia się do rozwoju gospodarczego i wzrostu standardu życia ludności. Pomimo popularności tego ujęcia, nie znajduje ono zastosowania dla wszystkich krajów. Szczególnie w przypadku małych, doganiajacych gospodarek otwartych, których rozwój jest $w$ dużej mierze uzależniony od efektywnej integracji $w$ ramach międzynarodowego podziału pracy, spojrzenie na źródta konkurencyjności jedynie przez pryzmat warunków wewnętrznych jest niekompletne. Bazując na uogólnionym modelu podwójnego diamentu przewag konkurencyjnych Moona (2000), w niniejszym artykule, podjęto próbę odpowiedzi na pytanie: w jak dużym stopniu powiazania gospodarcze z partnerami międzynarodowymi oraz działalność korporacji transnarodowych wptywaty na kształtowanie przewagi konkurencyjnej firm z krajów grupy Wyszehradzkiej oraz jak rola ta zmieniała się $w$ przypadku każdego z tych państw w okresie poakcesyjnym. W celu udzielenia odpowiedzi na to pytanie badawcze, zgromadzono dane z baz Eurostat oraz wskaźniki Global Competitiveness Report aby oszacować zmienne na poziomie krajowym i międzynarodowym. Wyniki przeprowadzonej analizy potwierdzaja, że integracja $w$ ramach gospodarki globalnej to ważny element konkurencyjności każdego z krajów grupy Wyszehradzkiej. 